\title{
Mulemba
}

Revista Angolana de Ciências Sociais

6 (11) | 2016

Políticas, direitos e práticas da sociedade e do Estado

\section{Brincando, humorizando e resistindo à ditadura militar brasileira: o bloco carnavalesco Pacotão na capital do Brasil (1978 - 2009)}

Playing, humoring and resisting the Brazilian military dictatorship: the carnival block Pacotão in the capital of Brazil (1978 - 2009)

José Walter Nunes e Alisson Lacerda de Andrade

\section{OpenEdition}

Journals

\section{Edição electrónica}

URL: http://journals.openedition.org/mulemba/1598

DOI: $10.4000 /$ mulemba.1598

ISSN: 2520-0305

\section{Editora}

Edições Pedago

Edição impressa

Data de publição: 1 maio 2016

Paginação: 269-293

ISSN: 2182-6471

Refêrencia eletrónica

José Walter Nunes e Alisson Lacerda de Andrade, «Brincando, humorizando e resistindo à ditadura militar brasileira: o bloco carnavalesco Pacotão na capital do Brasil (1978 - 2009)», Mulemba [Online], 6 (11) | 2016, posto online no dia 01 outubro 2018, consultado o 27 janeiro 2021. URL: http:// journals.openedition.org/mulemba/1598; DOI: https://doi.org/10.4000/mulemba.1598 


\title{
Brincando, humorizando e resistindo à ditadura militar brasileira: o bloco carnavalesco Pacotão na capital do Brasil (1978- 2009)*
}

\author{
José Walter Nunes ${ }^{* *}$ \\ Alisson Lacerda de Andrade ${ }^{* * *}$
}

\begin{abstract}
Resumo: O presente artigo tematiza as práticas carnavalescas da agremiação brasiliense Sociedade Armorial, Patafísica e Rusticana, o Pacotão, bloco carnavalesco que emerge em Brasília, República Federativa do Brasil, em 1978, num momento de forte resistência política dos grupos organizados da sociedade civil à ditadura militar, implantada desde 1964. As configurações e reconfigurações das experiências festivas do bloco ao longo dos trinta e dois anos de sua trajectória aparecem representadas neste estudo em canções, fantasias, faixas e narrativas orais, suportes empíricos deste trabalho. Ao compreender o carnaval de rua como uma manifestação cultural, o bloco Pacotão emergiu neste estudo como uma espécie de catalisador de tensões e conflitos político-sociais, constitutivos e reveladores das ambiguidades das relações de poder manifestas nas dimensões política, social e cultural da sociedade brasileira, na capital do país. Brasília ofereceu as condições que possibilitaram a experiência do Pacotão, e este recria a capital, carnavalizando-a, humorizando-a, tornando risíveis situações e personagens do quotidiano da cidade e da cena política brasileira.
\end{abstract}

Palavras-chave: Brasília, carnaval, ditadura, riso, história.

* Este artigo, com modificações, faz parte da pesquisa de dissertação de mestrado intitulada Experiências de um carnaval não organizado: a tradição de um bloco de sujos na Capital Federal (1978-2009) defendida por Alisson Lacerda de Andrade, e orientada pelo Prof. Dr. José Walter Nunes, em 2009, no Programa de Pós-Graduação em História, da Universidade de Brasília.

* Historiador, sociólogo e cineasta. Professor do Programa de pós-graduação em História (Linha de pesquisa: Imagens, narrativas, memórias) e do Programa de pós-graduação em Desenvolvimento, Sociedade e Cooperação Internacional (Área de concentração em políticas públicas), do Centro de Estudos Avançados Multidisciplinares da Universidade de Brasília.

*** Professor da Secretaria de Educação do Distrito Federal e pesquisador do Núcleo de Estudos da Cultura, Oralidade, Imagem e Memória, do Centro de Estudos Avançados Multidisciplinares da Universidade de Brasília. 


\section{Introdução}

Agremiação carnavalesca surgida em Brasília, capital do Brasil, no ano de 1977, o Pacotão, também conhecido por Sociedade Armorial Patafísica e Rusticana, realizou seu primeiro desfile em Fevereiro de 1978. Na ocasião, num domingo de carnaval, pouco mais de cem foliões, em sua maioria jornalistas - seus fundadores - incumbiram-se de realizar a festa pelas ruas e avenidas da capital.

Analisar as configurações, reconfigurações, rupturas, permanências e alternâncias das experiências carnavalescas vivenciadas em meio à folia do bloco de sujos ${ }^{1}$ que desafiou as amarras da ditadura militar pós 1964, caracteriza o foco do presente estudo, cujas observações de campo iniciaram-se em 2007.

De facto, em Fevereiro de 2007, no ápice das festividades carnavalescas de rua, as instalações e imediações do Bar Brasília, localizado na Avenida W3-Sul, na Quadra Comercial da 506, serviram de palco para o encontro festivo organizado pelos fundadores do bloco, onde seus trinta anos de história foram comemorados. O assunto das conversas, invariavelmente, era o mesmo: os carnavais dos tempos de outrora. A cada encontro entre os velhos parceiros de carnaval e, ou, profissão, as lembranças e recordações de um passado compartilhado encarregava-se de construir e reconstruir a memória colectiva do grupo. Mas em outro ponto da cidade, o mesmo e intitulado bloco, também festejava e comemorava os mesmos trinta anos de história da agremiação.

Estabelecidos na Entrequadra Comercial 302/303-Norte, foliões carregavam faixas, vestiam fantasias, entoavam canções e, sobretudo, também tomavam para si a tarefa de manterem vivas as tradições mencionadas. ${ }^{2}$ Ao som da marchinha Banho de Arruda,

1 Manifestação popular típica do carnaval de rua, onde o improviso caracteriza a festa, sendo as sátiras políticas uma das tónicas recorrentes na folia. A referência à ideia do sujo promove uma espécie de hierarquização social, colocando os festeiros na condição de quem deseja renascer socialmente, haja vista que se encontram nas linhas mais baixas da sociedade (DАматTA 1981: 128).

2 A noção de tradição empregada pela presente pesquisa encontrou suporte nas reflexões de Walter Benjamin, para quem a noção de tradição está relacionada a um saber-fazer - linguagem e prática - de determinados grupos sociais, cujas transmissões e incorporação se dão pelo acto de narrar, ritualizar, o que garante a continuidade dos grupos e a constituição de suas memórias, num quadro de constantes mudanças, geradas por dissensões e consensos internos (BENJAMIN 1986). 
referência ao então governador da capital, José Roberto Arruda, os foliões iniciavam o trajecto do desfile, partindo da altura da 302-Norte, passando pela Avenida W3-Norte, rumo à Avenida W3-Sul, pela contramão. $^{3}$

\section{Brasília: aqui o carnaval de rua é na avenida}

De um lado, foliões mais experientes referenciados e reverenciando os carnavais de outros tempos, dando ênfase aos feitos do passado que, ao serem evocados no presente, colaboram para a formulação das representações que fazem do bloco. ${ }^{4}$ Do outro, foliões que, embora também estivessem reverenciando os tempos idos, talvez direcionassem mais seus intentos ao objetivo de dar vazão a assuntos da vida local daquele momento, construindo, para tanto, suas próprias representações da festa. Entre essas disputas de memórias e representações, comparece a cidade, com suas características físicas, espaciais e humanas. Mas como essas dimensões dialogaram, influenciaram e ofereceram as condições de possibilidade para a existência da festa?

Brasília foi inaugurada em 1960. Planejada segundo os princípios da arquitetura e do urbanismo modernistas, foi inscrita na lista de Patrimônio Cultural da Humanidade pela Organização das Nações Unidas para a Educação, a Ciência e a Cultura (UNESCO) em 1987 e tombada/considerada pelo governo federal como Património Histórico Nacional em 1990. Desde o início de sua implantação, em 1956, no governo do presidente Juscelino Kubistchek, cientistas políticos, geógrafos, arquitetos, urbanistas, antropólogos, sociólogos, dentre outros, vêm estudando as modalizações da vida na capital (SINOTI 2005: 15).

3 Em 1978, domingo de carnaval, primeiro ano em que efectivamente desfilou o bloco, pouco mais de cem foliões partiram do Sector Comercial Sul rumo à Quadra Comercial Norte da 302. No mesmo ano, estes foliões já haviam realizado um desfile com trajectória semelhante, embora invertendo o fluxo, saindo, portanto, da 302 Norte rumo a destinos incertos da Asa Sul, passando pela W3-Sul, em seu sentido inverso, caracterizando o chamado baptismo na contramão.

4 A representação compreende a dimensão da realidade que fica entre o vivido e o concebido, sendo possibilitada pelas características sociais, políticas e históricas do contexto em que foi produzida. Também resulta de processos conflituosos em que estratégias de interesses e manipulações são constantemente adoptadas (PESAVENTO 1995: 15). 
Pensada desde o século xIx, ainda no Império, a cidade que viria a ser a nova capital do país teve seu território pesquisado intensamente. Contudo, dois períodos podem ser eleitos como os de maior relevância, no que toca à definição do chamado quadrilátero do Distrito Federal, ou seja, o território onde se implantaria a cidade: o período dos estudos da Comissão Cruls, ${ }^{5}$ em 1892, e Relatório Belcher, ${ }^{6}$ em 1956 (Ribeiro 2005: 21).

Lúcio Costa, autor do projecto urbanístico do Plano Piloto de Brasília, e Oscar Niemeyer - arquiteto mundialmente conhecido pelas curvas impostas a edificações singulares construídas nesta cidade - são nomes que figuram com destaque nos estudos que abordam a capital do Brasil em sua dimensão urbanístico-arquitetónica. Em termos gerais, poder-se-ia dizer que a dimensão modernista de Brasília é representada, sobretudo, pelas características funcionais que orientam a estruturação de seus espaços. A forte influência do pensamento de Le Corbusier, expoente da arquitetura moderno-funcionalista, na formação intelectual dos brasileiros acima citados, legitima a observação. ${ }^{7}$

Ademais, a noção de modernidade que atravessa a ideia de cidade da qual Brasília é, ao mesmo tempo, referência e resultado, veicula-se pela intenção de um modo de vida calcado em referências como funcionalidade, conforto, eficiência e racionalidade (MaTos 2005: 410). Assim, uma cidade que é zoneada por sectores, destinados à habitação, às actividades bancárias, comerciais, hospitalares, à administração pública, diversão, viu surgir, oficialmente, apenas no ano de 2008, a destinação de um espaço para a realização das

5 A Comissão Exploradora do Planalto Central, de 1892, foi chefiada pelo astrónomo Luiz Cruls. A comissão era composta por membros de instituições científicas brasileiras, além do Exército, com a participação de soldados e oficiais, todos egressos da então chamada Escola Superior de Guerra (VERGARA 2010).

6 Relatório feito pela empresa americana Donald Belcher \& Associates, que dividiu em cores as áreas onde a capital poderia estar localizada: verde, castanho, azul, amarelo e vermelho. O Sítio Castanho foi escolhido pelos membros da Comissão de Localização da nova Capital Federal.

7 Le Corbusier (1887-1965), arquitecto e urbanista suíço, considerado um dos mais importantes do século xx, inova em vários aspectos o pensamento arquitectónico e urbanístico da época. Um deles é sua concepção de pilotis nos edifícios, que dá a essas construções a ideia de suspensão no espaço, fonte inspiradora de Brasília. Um estudo que oferece instrutivos direccionamentos acerca da influência do modernismo francês no pensamento arquitectónico-urbanístico brasileiro pode ser encontrado em Carlos Lemos (1994). 
actividades carnavalescas, objecto de iniciativa popular. ${ }^{8}$ Localizado ao lado da Biblioteca Nacional, na Esplanada dos Ministérios, o espaço chamado Gran Folia, constituía-se, em tempos de carnaval, por uma estrutura que contava com instalações de banheiros, áreas de alimentação, palcos, e outros elementos de infraestrutura. O espaço foi destinado, principalmente, para o encontro dos blocos de carnaval de rua, embora não fosse exclusivo para eles. Uma das primeiras agremiações carnavalescas a aderir à proposta foi o Galinho de Brasília, ${ }^{9}$ o mesmo não ocorrendo com o Pacotão. ${ }^{10}$

Mas tendo em vista que qualquer cidade, em sua banalidade, é potencialmente rica pelas aventuras que suas ruas e lugares diversos secretam (MAFFESOLI 1984: 48), o que teriam a revelar as experiências carnavalescas vivenciadas nas ruas e avenidas da capital brasileira?

É certo que o Pacotão, em função de conflitos com autoridades, representantes de instituições governamentais e moradores das áreas residenciais por onde o bloco passa e, ou, já passou, ao longo de sua história, sofreu com alterações no trajecto de seus desfiles. Mas as mudanças, é importante frisar, provisórias ou não, ${ }^{\mathbf{1 1}}$ fizeram parte da própria dinâmica da festa, situação que pode revelar certas características da folia. Por um lado, as autoridades, tentando mapear para cercear, dominar, funcionalizar. Do outro, a festa, a espontaneidade, a cidade e suas dinâmicas, que como apontado, carrega o elemento da banalidade, que em si é potencialmente rico, posto que secreta aventuras, experiências, vivências.

8 É necessário informar que intervenções governamentais no carnaval das escolas de samba da capital têm sido constantes. Essas agremiações, primeiro desfilavam na W3-Sul. Depois, foram para o Eixo Rodoviário/Sul. Em seguida, para o Eixo Monumental, perto da Torre de Tv. Também já foram sediadas na Região Administrativa da Ceilândia!

9 O bloco Galinho de Brasília foi a primeira agremiação a aceitar a proposta do governo para a realização do carnaval 2009, e, coincidências à parte, também foi o primeiro a sofrer as consequências do processo de imposição e disciplina do uso dos espaços da capital, sendo impedido de permanecer, como de costume, no espaço onde tradicionalmente realizava sua folia.

10 Mais adiante serão explicitados os motivos que levaram os membros do bloco Pacotão a olharem com certa reticência à iniciativa do Governo. Cabe, no entanto, informar que a agremiação esteve presente no dia da abertura do carnaval brasiliense, realizada no espaço Gran Folia, em Fevereiro de 2008 (Correio Braziliense, Fevereiro de 2008).

11 Algumas das mudanças de trajecto do desfile serão apontadas mais à frente. 
São vivências de foliões que desafiaram, com muito humor, sarcasmo e irreverência, as amarras e interdições dum período histórico marcado pela repressão político-cultural, imposta pelo regime ditatorial, instaurado no país desde Março de 1964. Com efeito, as ruas e avenidas da capital, desde então, passaram a compreender o palco, a passarela e, sobretudo, o espaço simbólico da reprodução de diferentes ideias de cultura (SERPA 2007: 09) - cultura aqui entendida não apenas como modo de vida, mas como modo de luta, onde grupos exigem seu reconhecimento cultural e social, em uma sociedade marcada pela diversidade e pela diferença (NuNES 1993). Lutas por liberdade política, por direitos sociais, por reconhecimento cultural, por formas participativas de organização da sociedade, enfim, por liberdades democráticas. De facto, a folia do bloco Pacotão, tanto no passado como no presente, é uma manifestação cultural de crítica e contestação à ordem político-social vigente.

\section{Debochando a ditadura e balançando o Pacotão, nas lentes do bloco}

Retomemos o ano de 1978. Embalados ao som da canção Plataforma, composta por Aldir Blanc e João Bosco, como já dissemos, cerca de cem foliões tomaram as avenidas da capital naquele ano para festejar a folia de Momo. A mitologia grega trata Momo, filho do Sono e da Noite, como o deus da zombaria, do sarcasmo, da galhofa, do delírio, da irreverência e do achincalhe. Diante do seu costume de criticar e ridicularizar os outros deuses, a divindade maior do Olimpo perdeu a paciência com ele e despacha-o para a Terra, onde o divino deportado passou a ser representado por um jovem que tira a máscara e mostra o rosto zombeteiro, ao mesmo tempo em que sacode guizos e apresenta o estandarte da folia, razão da sua existência. Em entrevista concedida ao jornal Correio Braziliense, o jornalista Claudio Lysias, um dos fundadores do bloco, aponta que o objectivo inicial da festa era «criar uma tradição de carnaval de rua na cidade». E carnaval de rua, feito por bloco, implica zombaria, riso. Assim, num contexto marcado por incertezas frente aos rumos político-sociais da nação, um grupo de foliões, moradores da cidade, tomou para si o espírito anárquico e crítico, cantado na letra supracitada, ampliando-lhe sentidos e significados. 
O modo irónico de cantar os versos das marchinhas revelou-se importante ferramenta para camuflar as críticas que os integrantes do bloco endereçavam aos dirigentes políticos da nação, integrantes do regime ditatorial. Essa ferramenta foi utilizada, sobretudo, no período entre os anos de 1978 e 1984, época da chamada redemocratização do país: de um lado a sociedade pressionando pelo fim do regime e de outro o Estado resistindo, mas já com um discurso de que a abertura política deveria ocorrer de modo «lento», «gradual» $\mathrm{e}$ «seguro».

E foi assim que no carnaval de 1978, os festeiros que, também conhecidos como «pacoteiros», apropriaram-se das avenidas W3 Norte e Sul, transformando-as em passarelas de seu desfile. Nos lábios dos festeiros, a voz saltitante e desafiadora cantarolava:

\section{Por um bloco,}

Que derrube esse coreto,

Por passistas à vontade

Que não dancem o minueto. ${ }^{12}$

Certamente não criticavam apenas o desfile constituído nos termos propostos pelo padrão das Escolas de Samba: Não põe corda no meu bloco / Nem vem com teu carro-chefe. ${ }^{13}$ Embora estivessem falando acerca do carnaval, inclusive utilizando termos próprios à festividade momesca, a crítica tomada por empréstimo à canção Plataforma transcendia às discussões a respeito dos estilos ou modos de se fazer a folia. É possível perceber, embutidas ao discurso, críticas tanto ao regime militar, quanto às características funcionais da própria cidade planejada. Afinal: não dá ordem ao pessoal / não traz lema, nem divisa. ${ }^{\mathbf{1 4}}$ A quem não desejavam obedecer? Quais ou que divisões contestavam?

Não é possível, nem tampouco é objectivo aqui, precisar um sentido específico ao modo como os festeiros atribuíam sentidos às canções a que se apropriavam. Os foliões são sujeitos sociais inseridos numa colectividade, imersos a sensibilidades que não devem ser vistas em seu isolamento, mas pensadas como elementos integrados ao contexto e em conexão com outras instâncias (MATOs 2005: 426). E

12 Canção Plataforma: composição de Aldir Blanc e João Bosco.

13 Idem.

14 Idem. 
nesse caso, a pesquisa aborda um contexto marcado pelo processo de transição entre um regime militar, ditatorial, e uma, ainda, suposta promessa de democracia a ser reestabelecida.

Informação também importante a ser salientada, é o facto de que o grupo que fundou o mais antigo bloco de sujos da capital era formado, em sua maioria, por jornalistas, vindos de outros estados, em decorrência da oferta de emprego surgida por ocasião da cobertura dos eventos que marcavam a vida política brasileira naqueles anos. Sejam sectoristas, sejam cartunistas, eram profissionais que, via de regra, participavam, por meio da cobertura, dos assuntos da cena política nacional. ${ }^{15}$ É provável que tal característica profissional tenha influenciado no modo como buscaram significar e, assim, estabelecer sua folia carnavalesca, demonstrando e, sobretudo, reforçando que as festas operam como vitrines da própria alma das sociedades.

Muito já foi dito acerca dos motivos que levaram os jornalistas a terem criado o bloco Pacotão em Brasília. Afirmar que seu único objectivo consistia no desejo de brincar a festividade carnavalesca de modo diferente das formas até então existentes na capital, talvez seja uma interpretação reducionista. ${ }^{16}$ Por outro lado, afirmar que existia uma intenção política precedendo e direccionando as intenções, como se o carnaval fosse um pretexto para se instituir formas de se estabelecer críticas ao regime, talvez seja incorrer na mesma redução interpretativa. Para sair dessa amarra binária, pode-se pensar que diversas variantes influenciaram o processo de constituição do bloco, tendo o contexto político-social da época, as características espaciais e festivas da cidade, além das experiências culturais e políticas anteriores de seus fundadores, terem operado como factores que condicionaram o surgimento da folia.

A recorrente menção à ideia de bagunça, não organização, tão recorrente na história do bloco, oferecem importantes direccionamentos

15 Carlão Lysias, Carlos Augusto Gôuvea - o Carlão, David Renault, Fernando Lemos, Guarabira, Márcio Varela, Moacyr de Oliveira Filho - o Moa, e o Racsow - são considerados os fundadores do Pacotão. Informações obtidas no endereço <http://www.brasiliatur.com.br/pacotao_joanfi.htm> Data: o5 de Março de 2007, às 10:30 h/s.

16 Nesse período, as festas carnavalescas mais conhecidas em Brasília ocorriam nos clubes da cidade, chamadas de bailes de carnaval. No espaço da rua, tinha-se um carnaval oficial - entendido aqui como aquele das escolas de samba, as quais contam com apoio governamental e organizam-se de modo articulado com as normas definidas pelas instituições governamentais e particulares. Nessa época, a Avenida W/3-Sul era o palco do desfile dessas agremiações de samba. 
para a compreensão dos elementos que, embora diversificados, juntos corroboraram para a estruturação da festa. A canção Platafor$m a$, por mais uma vez, oferece direcionamento, conforme aponto os versos abaixo.

\author{
Que balance e bagunce \\ O desfile e o julgamento. \\ Que a gente não precisa \\ Que organizem nosso carnaval.
}

Mas o que queriam bagunçar? Bagunçar para quê? Ou, ainda, que tipo de organização rechaçavam? Talvez aqui os versos de outro poeta do cancioneiro nacional Chico Science, operem como direccionadores do olhar: «desorganizando eu posso me organizar / me organizando eu posso desorganizar». ${ }^{17}$ É importante reforçar aqui que a canção Plataforma, embora não tenha sido composta pelos foliões que fundaram o Pacotão, foi tomada por eles como musa inspiradora da folia, e como tal, operou como tónica a direccionar o festejo.

Mas e o carnaval? Quais possibilidades de interpretação são oferecidas pela dinâmica que encabeça esse tipo de festa?

O carnaval, conforme observa Roberto DaMatta, surge como uma imensa tela social, onde múltiplas visões da realidade são simultaneamente projectadas (DAMATTA 1981: 122). No Pacotão, o costumeiro uso de faixas pelos foliões, com inscrições de mensagens, ideias, pode ser entendido como uma das formas de projecção na festa da realidade social, prática vigente desde os primeiros desfiles do grupo. Vide imagem um em anexo.

Dentre as faixas, algumas merecem destaque, por exemplo: «tropecei na abertura» - alusão às controversas que envolviam o processo de abertura política iniciado em 1975, vigência do mandato presidencial do General Geisel - e, «Anestesia ampla, geral e irrestrita» - também referência ao processo de redemocratização, em que a sociedade reivindicava anistia aos presos políticos e aos exilados. A faixa mais conhecida da história da agremiação esboçava a junção de palavras em alemão organizadas na seguinte sequência: der Pacoton Lieben und Khu shey. O temido Serviço Nacional de Inteligência (SNI) deu tratamento diferenciado para ela. Seus agentes

17 Da lama ao caos (Nação Zumbi). Composição: Chico Science 
de informação, disfarçados de portugueses, acompanharam à distância o desfile de 1978. Ao final, não conseguiram desvendar o que talvez pensassem ser uma mensagem subversiva codificada.

É certo que não achariam nada, afinal, as ditas palavras não possuíam sentido coeso, tão pouco algum tipo de informação subversiva contra o regime instaurado, sendo apenas uma possibilidade de referência às origens germânicas do general Geisel, como também poder-se-ia pensar enquanto tentativa de colocar o presente político ditatorial brasileiro em contacto com o passado nazi-fascista da Alemanha. Lembrar tal passado naquele momento, significaria realçar a necessidade de resistir, de combater no presente o regime de força, instaurado com o golpe de estado de 1964. Enfim, a faixa prenunciaria um outro tempo, o tempo da liberdade, o tempo da democracia que ali na brincadeira de carnaval estava em construção e que haveria de chegar à sociedade para abolir a opressão política. Vide imagem dois em anexo.

Desse modo, é necessário atentar ao facto de que as frases citadas formam imagens, seguem critérios, ideias ou intenções, e são pautadas por um imaginário social constitutivo da época em que foram produzidas (Possamai 2007: 57). Vale enfatizar também que a visualidade opera como elemento central no fazer carnavalesco dos blocos de sujos. As fantasias, faixas e adereços não podem ser vistos como simples dados, coadjuvantes do estudo, haja vista que constituem o modo como os foliões buscam e, ou, buscaram representar a realidade social a qual estão/estavam inseridos, sinalizando, assim, intenções, desejos, anseios, vontades.

\section{Charles Preto abre alas para o desfile na contra- mão: tácticas, astúcias para driblar a repressão}

Dar ênfase à ideia de que a festa apresentada pela agremiação não passava de mera brincadeira, certamente foi uma das tácticas utilizadas pelos foliões do Pacotão para evitar possíveis retaliacções por parte da repressão. Retomando aqui as motivações que convergiram para a formação do bloco, faz-se instrutivo anotar que, no primeiro carnaval da agremiação, as referências ao regime militar não ocorreram na mesma intensidade que no ano seguinte, o que de modo algum significa que o regime tenha passado despercebido naquele ano. A canção Plataforma, embora tenha entrado para a história do 
bloco como musa inspiradora da festa, não foi a canção oficial do desfile daquele ano, cabendo à marchinha Saudade da Beleza, composta por integrantes da agremiação, esta função.

\author{
O Pacotão \\ Com saudade da beleza \\ Saúda o povo \\ E revela com tristeza \\ Que seu carnaval \\ Não existe mais, \\ O Pacotão \\ $\hat{O}, \hat{o}, \hat{o}, \hat{o}$, quem tinha razão \\ Era o meu avô \\ $O \ll$ Pacotão» ${ }^{18}$
}

Nenhuma menção à ditadura foi pronunciada na canção. Uma mistura de nostalgia com saudosismo revelava o desejo de retorno aos antigos carnavais, tendência que marca o fazer carnavalesco desses foliões naquele momento. Porém, o próprio nome do bloco já estava associado a assuntos da vida política brasileira. O símbolo e mascote da festa, uma tartaruga, já à época fazia referência ao contexto sociopolítico do período, representando o ritmo da abertura política nos termos colocados pelo governo Geisel, para quem ela deveria ser lenta, segura e gradual.

Para DaMatta, conforme já dito, o carnaval surge como uma imensa tela social, onde múltiplas visões da realidade são simultaneamente projectadas. Foliões são, antes de tudo, sujeitos sociais interpelados por valores, por experiências compartilhadas e constituídas a partir da relação com o outro, em um espaço e tempo definidos. Parte das experiências individuais dos festeiros que aderiram à proposta carnavalesca do Pacotão projectou-se na festa na forma de representações, sendo essas, selecções e, ou, fracções da realidade, condicionadas às características do contexto a partir das quais foram constituídas.

Tais representações encontram-se entre o vivido pelos foliões e o concebido pelos mesmos. Noutras palavras, cada representação da

18 «Saudade da Beleza», marchinha composta em 1978 por Claudio Lysias, Guarabira e Carlão, fundadores da agremiação. 
realidade social construída pelos festeiros durante a realização dos desfiles - fantasias, faixas, canções, narrativas orais, e outros - não somente é possibilitada pelas características sociais, políticas e históricas do contexto em que foram produzidas, mas, sobretudo, resultam de um processo conflituoso em que estratégias de interesses e manipulações de pessoas e grupos são constantemente adoptadas (Pesavento 1995: 15). Nessa direcção, torna-se oportuna a reflexão a respeito das configurações e reconfigurações da festa, trabalhando, em grande medida, seu aspecto lúdico.

O carnaval apresentado pelo Pacotão é antes de tudo uma brincadeira, como já dito anteriormente. E a brincadeira é constitutiva das folias carnavalescas. Mas teriam os militares se preocupado com as atitudes, falas e brincadeiras de um grupo de foliões que vez ou outra intitulavam-se de loucos? E por que haveriam de se preocupar com as falácias e risos de integrantes de um bloco de sujos, cuja característica histórica remonta à essência autoproclamada de serem os mais baixos entre os mais baixos, aqueles que se encontram nos porões e esgotos sociais? (DAMATTA 1981: 127).

É certo que havia por parte das autoridades do regime ditatorial algum tipo de preocupação com a folia. Relatos de agressões a jornalistas, episódios dos agentes do SNI (o temido Serviço Nacional de Informação da ditadura) infiltrados nos carnavais da época corroboram com este entendimento. No entanto, não é correcto afirmar, com base nas informações a que este estudo teve acesso, que os militares tenham elaborado algum tipo de vigilância sistematizada, com vistas à inibição de toda e qualquer acção julgada subversiva durante os dias de desfile do Pacotão.

De facto, historicamente, como esclarece DaMatta, existe no Brasil a suposição de que durante o carnaval nada do que acontece é sério (DAMATTA 1986: 122). Ou ainda, o carnaval é um momento sem dono, posto que é de todos (DamatTa 1981: 122). Mas como diz 280 a sabedoria popular: o seguro morreu de velho. Talvez por isso os dirigentes do bloco não tenham desejado pagar para ver. E assim sendo, o núcleo dirigente do bloco, chamado Politburo, ${ }^{19}$ escolheu

19 A autodenominação do grupo criador e director do bloco carnavalesco de Politburo soava como ironia à ditadura brasileira que denominava sempre seus opositores políticos de comunistas a serviço da então URSS (União das Repúblicas Socialistas Soviéticas) e que tinha o Politburo como comité executivo máximo dessa união. 
o personagem Charles Preto como presidente vitalício e ditador perpétuo da agremiação. E quem seria esta personalidade?

Charles Preto, figura emblemática e simbólica do Pacotão ou Sociedade Armorial, Patafísica e Rusticana, desde seus primeiros carnavais, compareceu nos dias da festa para conceder entrevistas, assinar notas oficiais, brigar, protestar, reclamar, inventar novidades e até aparecer na televisão. ${ }^{\mathbf{2 0}}$ Diz a lenda que existiu um tempo em que configurou desafio para os jornalistas da cidade designados para cobrir o carnaval do bloco - falo dos jornalistas menos experientes - conseguir uma exclusiva com essa personalidade do Pacotão. ${ }^{21}$ Tratava-se de uma tarefa impossível, já que o lendário e corajoso Charles Preto não passava de um mero personagem fictício, cujo nome consistia num trocadilho com o nome de Carlos Black, director do Departamento de Turismo/Detur, do governo local, à época da fundação da agremiação.

No primeiro desfile dos pacoteiros, nome dado aos foliões que participam e, ou, participaram do desfile do Pacotão, esse director de turismo ameaçou não permitir sua passagem pela W/3 Sul, uma vez que naquele espaço já eram realizados os desfiles oficiais das escolas de samba do carnaval de Brasília. O Pacotão não somente passou, como o fez pela contramão, carregando o boneco de Charles Preto como forma de ironizar a decisão do então director do Detur. Caso as autoridades do regime militar procurassem os responsáveis pela festa, ou tentassem atribuir responsabilidades a algum membro do bloco, teriam de procurar tanto por seus dirigentes - Politburo - quanto por seu presidente - Charles Preto - haja vista que para efeitos legais, o corpo dirigente é quem responderia pelas acções da agremiação.

A mesma estrutura de poder do bloco continua até os dias actuais. Para todos os efeitos de desfeitos, procurem Charles Preto. Vide imagem três em anexo.

\section{O poder do riso como instrumento de crítica}

O recurso ao riso como instrumento de crítica, de acordo com Soihet, «revela uma prática muito antiga, que remontaria a um

20 Correio Braziliense: Fevereiro de 1978.

21 Artigo de Moacir Oliveira Filho, op. cit. 
período da história da humanidade anterior à própria formação do Estado, quando os aspectos sérios e cômicos tinham peso idêntico» (Soinet 1998: 13). A chamada derrisão, prática recorrente nos blocos de sujo, é caracterizada pelo riso de zombaria, ridicularização, escárnio (Propr 1992: 28). Existem subcategorias no universo do riso, mas em essência, riem as pessoas e o que exactamente é ridículo para elas (PROPP 1992: 29).

No carnaval de 1981, uma das faixas que mais chamaram a atenção no bloco Pacotão trazia a seguinte expressão: Estamos com o Pires na mão, referência ao então Ministro do Exército, general Walter Pires. Já em 1982, Leitão de Abreu assumia a chefia do Gabinete Civil, substituindo um dos mentores da ditadura, o general Golbery do Couto e Silva. A agremiação não poderia deixar de prestar-lhe sua homenagem. Leitão ao molho Alemão, assim expressava uma das faixas no desfile de 1982. Quer dizer, os foliões da Sociedade Armorial, Patafísica e Rusticana tinham, cada vez mais, como mote inspirador e alvo de sua derrisão as figuras que ocupavam papel de liderança política no regime militar instituído. Estes festeiros julgavam, em parte, ridículas as atitudes, as posturas, as acções daqueles que governavam a nação. Assim, formou-se uma das mais fortes características do bloco: a sátira política. Mas o que caracterizaria a sátira?

O campo da sátira baseia-se na derrisão, isto é, no riso de zombaria e escárnio (Propp 1992: 28). Na sátira, «[...] a presença de suas personagens possibilita o desenvolvimento de um conflito, de uma luta, de uma intriga. Cada uma dessas personagens pode ter a seu redor um grupo de adeptos ou de parceiros» (PROPP 1992: 99). O autor ainda explica que a vítima da sátira manifesta no acto sua própria imbecilidade, causada, às vezes, pela própria culpa do satirizado. No embate travado entre os personagens, uma das partes pode ser desmascarada, de tal modo que fique à mercê do escárnio geral 282 (Propp 1992: 100). Pode-se dizer que um dos envolvidos no conflito acaba sendo feito de bobo.

No carnaval de 1980, o bloco fez menção à crescente inflação que assolava o País, atribuindo responsabilidades aos governantes que, além de não terem competência para gerir a economia nacional, ainda se envolviam em situações constrangedoras como as ocorridas em Santa Catarina, quando o general presidente Figueiredo, revelando seu temperamento considerado explosivo, reagiu às vaias que o povo lhe proporcionava no espaço público, chegando a quase sair 
às tapas com os manifestantes. ${ }^{22}$ Os foliões do Pacotão não deixaram passar em branco o episódio. A marchinha daquele ano além de falar da crise económica fez menção ao temperamento do general:

Subiu a carne,

Subiu a gasolina,

Subiu o feijão

e também a margarina.

Ai, ai, João

Eu vou pagar

A inflação com serpentina [...]

$A i, a i$, João

Vou te mandar lá pra Santa Catarina ${ }^{23}$

Ano após ano, a crítica pelo riso se tornava mais acentuada, as sátiras tornavam-se marcas da festa e os homenageados pelo bloco eram tratados como bobos, motivos de chacotas. Em 1982, ano em que Figueiredo sofre seu primeiro infarto do miocárdio, Golbery de Couto e Silva afasta-se do Gabinete Civil, entrando em seu lugar o professor Leitão de Abreu. O Pacotão mesclou aspectos da vida político-económica da época com situações pinçadas do contexto político de anos anteriores, para assim cantar:

Olha o rabo, olha o rabo

Olha o rabo que a porca torceu,

Olha o rabo, olha o rabo.

Olha o rabo, que a porca torceu.

Um disco voador desceu

E um leitão apareceu

Hoje em vou pro Tejo

Porque aqui a vaca vai pro brejo

Olha o rabo. Minha mãe sempre dizia

Que mentira só dá bode

De tanto fazer Pacote

Quase que explode

Olha o rabo. ${ }^{24}$

\footnotetext{
22 Informações obtidas no encarte do LP lançado pelo Bloco Pacotão, em 1985.

23 Santa Catarina: composição de Carlão, Cristiano Menezes e Rubens Artigas.

24 Olha o Rabo: composição de Carlão e Fernando Barros.
} 
Versos com sentidos dúbios ou paradoxais encontravam na palavra escrita (faixas), ou nas palavras cantadas (marchinhas), a imagem jocosa a ser ironicamente representada. Propp explica que sob a forma de paradoxo podem ser expressos também pensamentos sarcásticos e de escárnio. Revela ainda que a própria ironia pode ser utilizada de forma satírica (PROPP 1992: 126). No carnaval de 1983 esses recursos podem ser percebidos na composição da marcha que embalou o desfile do ano. E ainda sob o reflexo das eleições de 1982 - quando a oposição elegeu dez governadores, sendo um deles Leonel Brizola, pelo estado do Rio de Janeiro - estando o Brasil imerso às dificuldades económicas constitutivas de um país dependente das políticas do Fundo Monetário Internacional (FMI), salários congelados, inflação em alta, e outros, o Pacotão tomou as ruas da Capital para cantar:

\author{
Brasil, Brasil, Brasil. \\ Brasil, Brasil, Brasil. \\ Foi Pedro Álvares quem te pariu. \\ Vai fundo, Brasil, vai fundo \\ O FMI é o fim do mundo [...] \\ Doril, doril doril. \\ Nosso salário vai pra fora do Brasil \\ Doeu, doeu, doeu. \\ Mas Figueiredo é quem se perdeu. ${ }^{25}$
}

Versos que falam, mas não dizem - Foi Pedro Álvares quem te pariu; doeu, doeu, doeu, Mas Figueiredo é quem se perdeu - ou, dizem, mas não falam, formam a marchinha que em si já denuncia certas mudanças nas relações sociais e políticas do contexto em que foi produzida. O regime militar já demonstrava certo esgotamento no uso da repressão política. A festa de Momo de 1984 ficou conhe284 cida, na cidade, como o carnaval das Diretas Já, período de grande clamor político-social pelo fim do regime militar. Diretas Já foi um movimento civil nacional de reivindicação por eleições presidenciais directas no Brasil, tendo seu ponto alto em 1984. A possibilidade de eleições directas para a Presidência da República veio à tona com a

25 Brasil, Brasil, Brasil: composição de Nelson Pantoja, Pelágio Gondim e Josafá Dantas. 
proposta de Emenda Constitucional Dante de Oliveira, colocada no Congresso Nacional. Entretanto, quando da votação, no dia 25 de Abril daquele ano, a proposta foi rejeitada pela maioria dos parlamentares que tinha seus interesses vinculados à ditadura e a ela se subordinava e fazia sua defesa. A não aprovação gerou uma frustação em grande parte da sociedade brasileira, que participou desse movimento. ${ }^{26}$ Naquele ano, de grande mobilização política, o folião brasiliense tomou as ruas da Capital, sendo o Pacotão o grande catalisador das manifestações Pró-Diretas na cidade. Faixas foram erguidas com frases sarcásticas que clamavam: «indirectas jaz»! Embora o oposto fosse o desejado. Vide imagens quatro e cinco em anexo.

Ao mesmo tempo anunciavam: Necrotério Eleitoral - sentença condenatória ao Colégio Eleitoral. ${ }^{27} \mathrm{Ou}$ ainda: Sabe com que está falindo? - referência à crise que, no período, abalava as estruturas da economia nacional.

A marchinha que embalou o desfile de 1984 direccionou um conselho incisivo ao Presidente Figueiredo:

\author{
Não adianta mais enrolar, \\ é agora, ta na hora, vamos lá, \\ ninguém me segura, \\ sai da minha frente, \\ eu este ano \\ vou votar pra presidente. \\ Chega de conversa mole, \\ Ninguém engole
}

${ }^{26}$ Ainda assim, os adeptos do movimento conquistaram uma vitória parcial em Janeiro do ano seguinte, quando um de seus líderes, Tancredo Neves, foi eleito Presidente da República, pelo voto indirecto, no chamado Colégio Eleitoral esse era constituído por 66 senadores, 310 deputados, 132 representantes das maiorias das assembleias legislativas estaduais, seis por estado; num total de 508 votos - instituído pelo regime militar, em uma mudança constitucional ocorrida em 1969. Tancredo Neves, que faria a transição do regime militar para o civil, adoece e morre, não chegando a tomar posse. Seu vice, José Sarney, aliado do regime militar e um dos seus principais interlocutores, no calor dos movimentos sociais, rompe com a ditadura, assume a Presidência. Inicia-se assim, de modo institucional, a retomada do governo civil no Brasil, carregando no seu interior traços do autoritarismo do governo militar, até aos dias actuais.

${ }^{27}$ Durante a vigência da Ditadura Militar instaurada no país, a partir do golpe de 1964, cabia ao Colégio Eleitoral eleger o presidente e o vice-presidente da República. 


\section{O tal colégio eleitoral \\ Cai na real general. ${ }^{\mathbf{2}}$}

Mais que nunca, o desfile do Pacotão havia se tornado um ponto de convergência das críticas políticas proferidas pelos moradores da cidade. Esses, ao participarem de seus desfiles, davam-lhes os traços de suas convicções políticas e experiências diárias com e na Capital. Vide imagem seis em anexo.

\section{Conclusões}

Analisar as configurações, reconfigurações, rupturas, permanências e alternâncias das experiências carnavalescas vivenciadas em meio à folia carnavalesca do bloco Pacotão, implica acessar dimensões da vida política e social não só brasiliense, mas nacional. A cidade e o país compareceram representados pelas lentes bem humoradas de festeiros que, em meio a disputas, conflitos, harmonias e negociações, forjaram, à sua maneira, representações de contextos sociopolíticos compartilhados.

Seja no período em que vigorou a Ditadura Militar, entre as décadas de 1960 e 1980, contexto marcado pela supressão de direitos, repressão política e social, extinção da liberdade de expressão, seja após esse período, com o retorno à democracia, os foliões actualizaram as práticas que aqui são apontadas como constitutivas de uma tradição carnavalesca. A Sociedade Armorial, Patafísica e Rusticana, o Pacotão, tornou-se tradição no carnaval brasiliense, sobretudo, por ter se tornado um dos pontos onde se aglutinam experiências festivas do passado e do presente da cidade, articulando experiências individuais e colectivas, compartilhadas, resignificadas e actualizadas por seus moradores.

Sondar sentidos para a história do bloco carnavalesco Pacotão significa acessar múltiplas experiências, sejam elas festivas, sejam elas políticas e, ou, sociais. Ora criticando o poder político constituído, ora reproduzindo-o, carnavalizando-o por meio do humor debochado, os foliões disputam o direito de representar à sua maneira 0 contexto da época em questão. O bloco de carnaval de rua Pacotão,

${ }^{\mathbf{2 8}}$ Cai na real general: composição de Ivan Sérgio e Haroldinho de Santo Amaro. 
por ser uma manifestação cultural ambígua (CHAUí 1985: 122), tornou-se espaço para a manifestação de expressões e posicionamentos políticos e ideológicos diversos, tornou-se instituição não institucionalizada, tradição que é mudança permanente, espaço de poder e espaço de riso, espaço de vida. Conforme aponta um dos principais militantes da causa desse bloco, Paulão do Varadeiro, o Pacotão é o papel higiénico da história, ${ }^{29}$ por isso, imaginamos, ele pode ser pensado como espaço de construção de uma outra história, narrativa que se faz a contrapelo da história e historiografia dos grupos dominantes; na verdade, o Pacotão, com práticas carnavalescas que utilizam várias linguagens, inclusive metafóricas e alegóricas, construiu e constrói memórias que acabam se inscrevendo no campo de uma contra-história, risível e transformadora.

\section{Referências bibliográficas}

BENJAMIN Walter 1987, Magia e técnica, arte e política. São Paulo, Editora Brasiliense.

CHAuí Marilena 1986, Conformismo e resistência. Aspectos da cultura popular no Brasil. São Paulo, Editora Brasiliense.

D’araujo Maria Celina e CAStro Celso (orgs.) 1997, Ernesto Geisel. Rio de Janeiro, Edição da Fundação Getúlio Vargas.

DAmatTa Roberto 2001, O que faz o brasil, Brasil? Rio de Janeiro, Editora Rocco. 1981, Carnavais, malandros e heróis. Rio de Janeiro, Zahar Editores.

\section{Lemos Carlos}

1994, O que é Arquitetura? São Paulo, Brasiliense.

MAFFESOLI Michel

1984, A conquista do presente. São Paulo, Editora Rocco.

Matos M. Izilda

2006, «Âncora de emoções. Poética e música em Dolores Duran», in História e Sensibilidade. Brasília, Paralelo 15.

29 Trecho de entrevista concedida pelo folião, dirigente da Agremiação, Paulão do Varadeiro. 


\section{Mello Maria T. Negrão de}

1997, «Cascariguindum, cotidiano, cidadania e imaginário na obra de Adoniran Barbosa», in Albene M. Menezes (org.), História em Movimento. Temas e perguntas. Brasília, Editora Thesaurus.

Negrão de Mello Maria, ver Mello Maria T. Negrão de, supra.

NunEs José Walter

2005, Patrimônios subterrâneos em Brasília. São Paulo. Editora Annablume.

Pesavento Sandra Jatahy

2008 (2. ${ }^{\mathrm{a}}$ edição), História e história cultural. Belo Horizonte, Editora Autêntica.

1995, «Em busca de uma outra história. Imaginando o imaginário», Revista Brasileira de História (São Paulo), vol. 15, n. ${ }^{\circ}$ 29, pp. 9-27.

Possamai Zita Rosane

2007, «Narrativas fotográficas sobre a cidade», Revista Brasileira de História (São Paulo), vol. 27, n. ${ }^{\circ}$ 53, pp. 7-23.

Propp Vladimir

1992, Comicidade e riso. Tradução de Aurora Fornoni Bernardini e Homero Freitas de Andrade. São Paulo, Editora Ática.

RIBEIRo Sandra Bernardes

2005, Brasília: Memória, cidadania e gestão do patrimônio cultural. São Paulo, Editora Annablume.

SERPa Ângelo

2007, O espaço público na cidade contemporânea. São Paulo, Editora Contexto.

SinOTI Marta Litwinczik

2005, Quem me quer, não me quer Brasília, Metrópole-Patrimônio. São Paulo, Editora Annablume.

SoIHET Rachel

1998, A subversão pelo riso: Estudos sobre o carnaval carioca da Belle Époque ao tempo de Vargas. Rio de Janeiro, Fundação Getúlio Vargas.

Vergara Moema de Rezende

2010, «A Comissão Cruls e o projeto de mudança da Capital Federal na Primeira República», in Nelson de Castro Senra e Nísia Trindade Lima (orgs.), Veredas de Brasília. As expedições geográficas em busca de um sonho. Rio de Janeiro, IBGE, Centro de Documentação e Disseminação de Informações, pp. 36-50. 
Anexo

Imagem 1

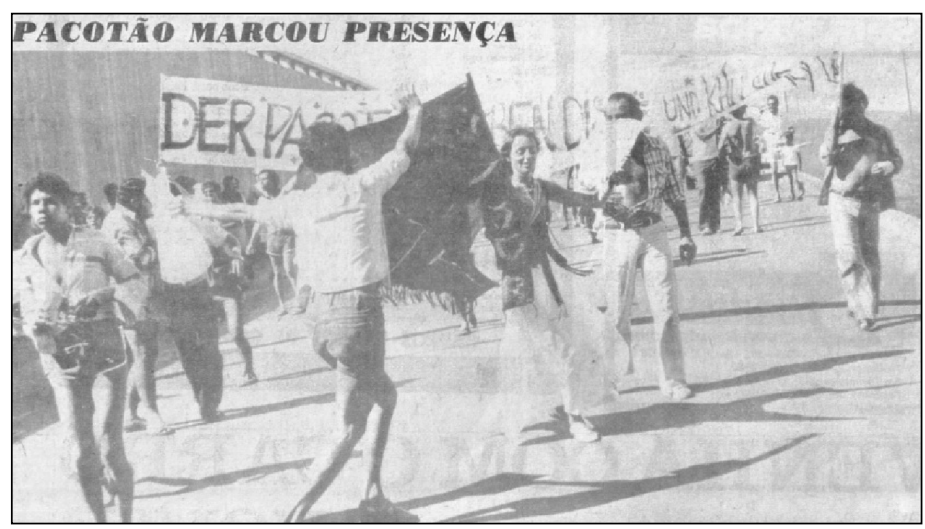

Fonte: Correio Braziliense, p. 8, Fevereiro de 1978

\section{Imagem 2}

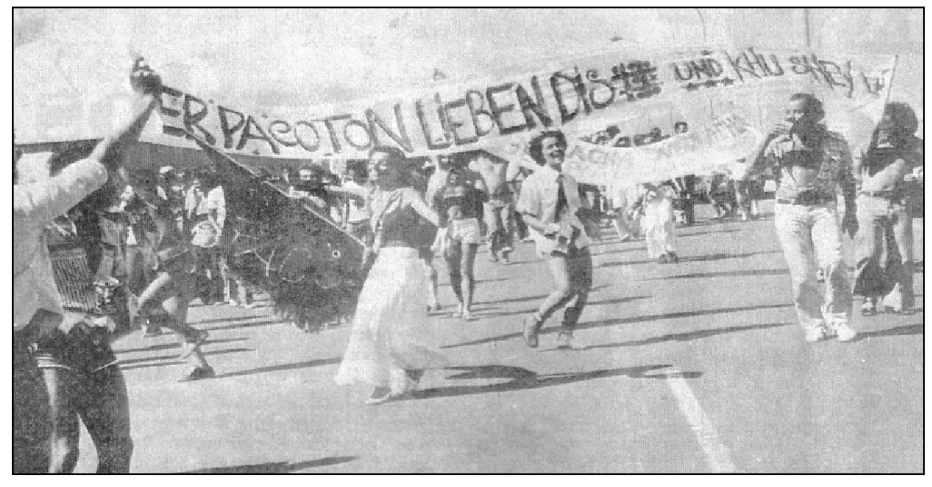

Fonte: Correio Braziliense, p. 9, Fevereiro de 1978 


\section{Imagem 3}

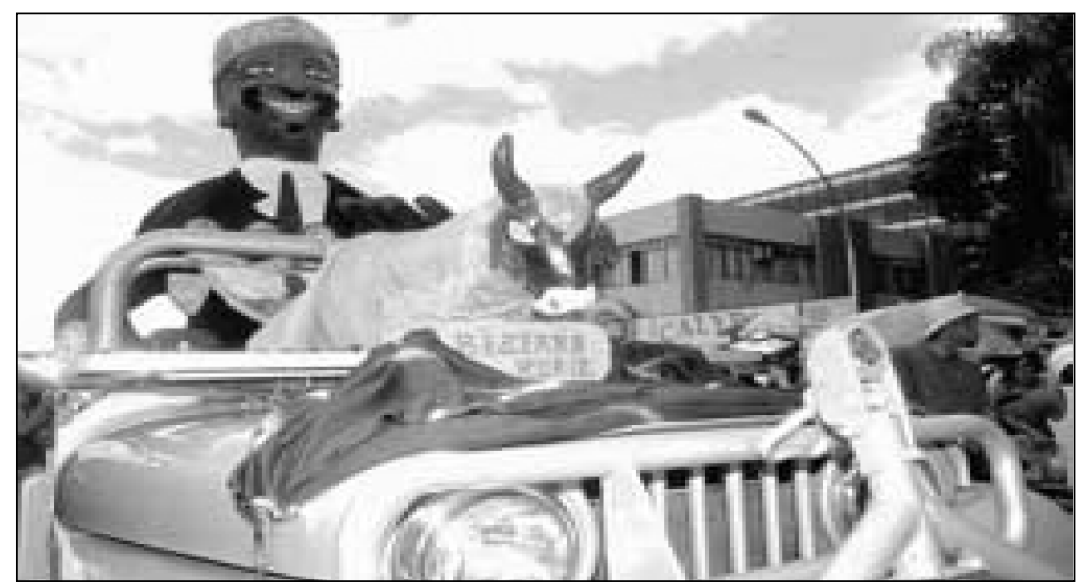

Fonte: Correio Braziliense, p. 12, Fevereiro de 2007

\section{Imagem 4}

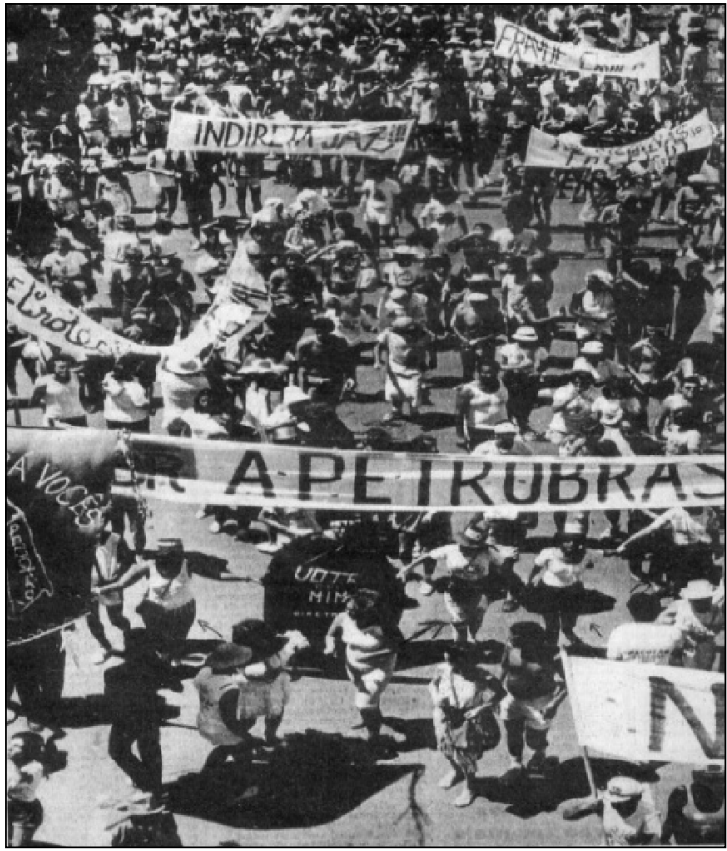

Fonte: Correio Braziliense, p. 15, Fevereiro de 1984 
Imagem 5

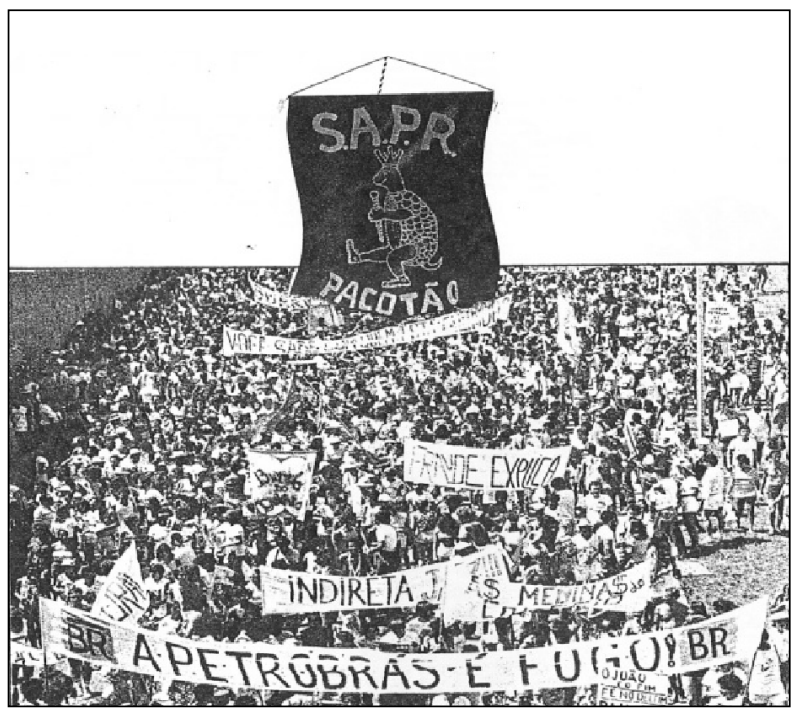

Fonte: Capa do primeiro vinil gravado pelo bloco em 1985

\section{Imagem 6}

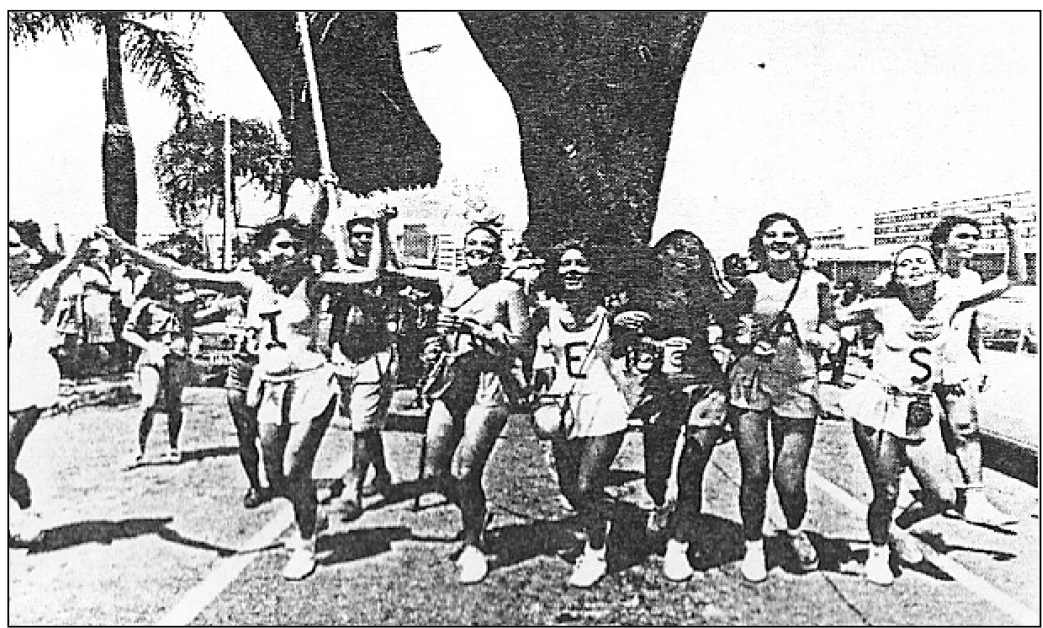

Fonte: Encarte do primeiro vinil gravado pelo bloco em 1985 
Artigo solicitado aos Autores

Recepção do manuscrito: 02/09/2016

Aceite para publicação: 15/10/2016

Title: Playing, humoring and resisting the Brazilian military dictatorship: the carnival block Pacotão in the capital of Brazil (1978 - 2009)

\begin{abstract}
This paper thematizes the carnival practices of the block Club Sociedade Armorial, Patafísica e Rusticana, the Pacotão (Huge Package), carnival group that emerged in Brasilia, Brazil, in 1978 , at a time of strong political resistance from organized civil society groups to the military dictatorship, deployed since 1964. The configurations and reconfigurations of festive block experiences over thirty-two years of his career appear represented in this study songs, costumes, banners and oral narratives, empirical supports this work. By understanding the street carnival as a cultural event, the Pacotão block emerged in this study as a kind of catalyst for tensions and political and social conflicts, constitutive and revealing the ambiguities of power relations manifest in the political, social and cultural dimensions of Brazilian society in the nation's capital. Brasilia offers the conditions that allows the experience of Pacotão, and it recreates the capital, carnivalizing it, humorizing it to make laughable situations and characters in the life of the city and the Brazilian political scene.
\end{abstract}

Keywords: Brasília, carnival, dictatorship, laugh, history.

\title{
José Walter Nunes
}

Pós-Doutor em Cinema e História pela Universidade de Buenos Aires, Doutor e Mestre em História Social pela Universidade de São Paulo (usp), Graduado em Ciências Sociais (Sociologia) pela Universidade de Brasília (unB) e fez de modo paralelo sua formação no campo do cinema/vídeo documentário. Na Universidade de Brasília é Professor do Programa de Pós-Graduação em História (Linha de pesquisa: Imagens, narrativas, memórias) e do Programa de pós-graduação em Desenvolvimento, Sociedade e Cooperação Internacional (Área de concentração em Políticas Públicas), do Centro de Estudos Avançados Multidisciplinares (CEAM). Neste centro, no Núcleo de Estudos da Cultura, Oralidade, Imagem e Memória, é sociólogo, pesquisador e docente na graduação. Seu campo de pesquisa e docência está voltado para os seguintes temas: história, memória, cultura, imagem, história oral, identidade, interculturalidade, património, com foco no estudo das relações entre história e audiovisual (cinema e vídeo) e políticas públicas. A maioria dos personagens de suas pesquisas académicas e documentários têm sido as pessoas e grupos comuns da sociedade brasileira.

[e-mail: nunesjw@gmail.com] 


\section{Alisson Lacerda de Andrade}

Mestre em História pelo Programa de Pós-graduação em História da Universidade de Brasília (PPGHIS-unB) e Especialista em Gestão Educacional. É professor da Secretaria de Educação do Distrito Federal e pesquisador do Núcleo de Estudos da Cultura, Oralidade, Imagem e Memória, do Centro de Estudos Avançados Multidisciplinares (CEAM), da Universidade de Brasília (unB).

[e-mail: andradedf1o@yahoo.com.br] 